\title{
Histopathological study of caseous necrosis in lungs of sheep in Diwaniya province
}

\author{
K. G. Ch. Al-Nailey \\ Coll.Vet. Med. /UniveAl-Qadisiya
}

\begin{abstract}
The specimens collect from Al Diwanya slaughter; we collect about 21specimens (lungs of sheep),all these specimens contained lesions with cheesy like appearance.The specimens cut and prepared for histopathological sections from it, then stained with haematoxyline and eosin stain, we note granulomatous lesion characterized by caseous necrosis in centre (like cheese) also we note fibrosis and inflammatory process includes sever infiltration of macrophages and lymphocytes with presence of giant cells ( which indicate the chronic diseases such as tuberculosis, John's disease or diseases which characterized by sever fibrosis such as fungal or parasitic diseases).
\end{abstract}

\section{Introduction}

The term of NECROSIS consists of tow words: (Necro-death, osis - state).This is the term applied to the state of cell death. Essentially this means death of a tissue (cell death on a large scale) or part of a tissue with cellular reaction to the dead cells (1). Necrosis is the name given to premature death of cells and living tissue.It caused by external factors, such as infection, toxins, or trauma (2).Cellular necrosis can be induced by a number of external sources, including injury, infection, cancer, infarction, poisons, and inflammation. For example, an infarction (blockage of blood flow to muscular tissue) causes necrosis of muscle tissue due to lack of oxygen to the affected cell, such as occurs in a myocardial infarction -- a heart attack (3).There are some conditions must be differentiate from necrosis, such as autolysis which means lyses of tissues by their own enzymes, following the death of the organism. Therefore, the key difference

\section{Materials and methods}

After collection of specimens which taken from infected lungs, specimens were preserved in $10 \%$ buffered neutral formalin in a glass container, closed tightly and kept under room temperature until examination. After transportation of specimens to the laboratory of anatomy and histology in veterinary medicine college Al-Qadisiya University for

\section{Results}

Macroscopic lesion:

The macroscopic lesion characterized by nodular pattern usually yellowish green 
appearance, caseous or cheesy like appearance present in the center of lesion. Occasionally its appearance may be purulent. The caseous centre is usually dry, firm and covered with a fibrous connective capsule of varying thickness. Lesion size ranges from small enough to be missed by the unaided eye, to involvement of the greater part of the lung.

\section{Microscopic examination:}

From histopathologically examined lung tissues sections, granulomatous lesion with caseous necrosis in center of lesion were observed in the lungs (figure 1).The granulomatous lesion in the pulmonary tissue of infected sheep, consisted of a collection of inflammatory cells (lymphocytes and macrophages) within the infected tissue (figure 2). Also the microscopic slides demonstrated infiltration of third line of inflammatory process is multinucleated langhans giant cells (which have horse shoe nuclei) (figure 3) \& (figure 4) , these type of cells formed due to Many macrophages (2_12) cells may united together to formed it. The accumulation of living and dead macrophages, lymphocytes, multinucleated giant cells, bacteria and tissue cells around caseous necrosis in centre comprises a granuloma. A thick fibrous capsule may form around these granuloma (figure 5).

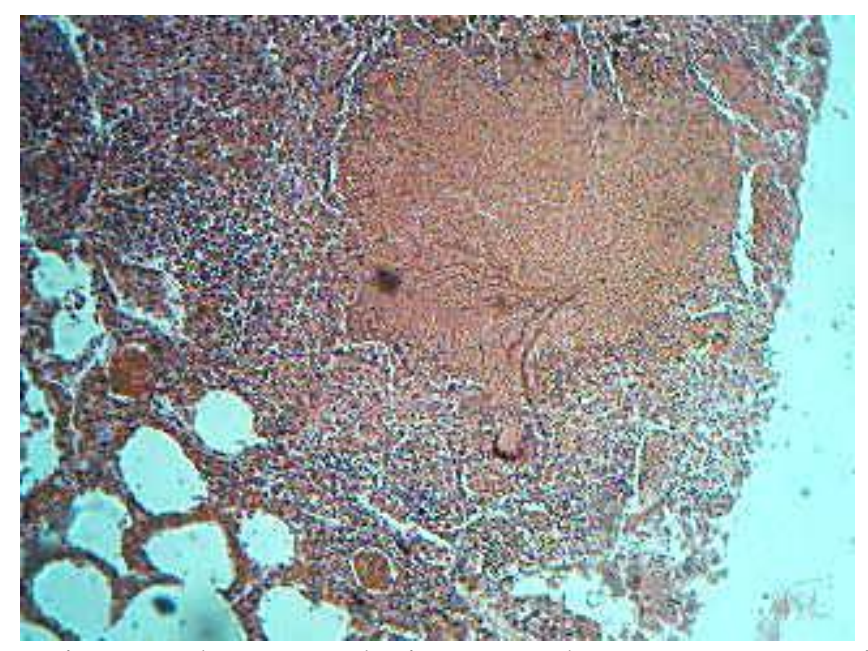

Fig.(1): Lung : There is granulomatous lesion note the caseous necrosis in center of lesion and infiltration of inflammatory cells (Macrophages \& Lymphocytes). 50X H\&E.

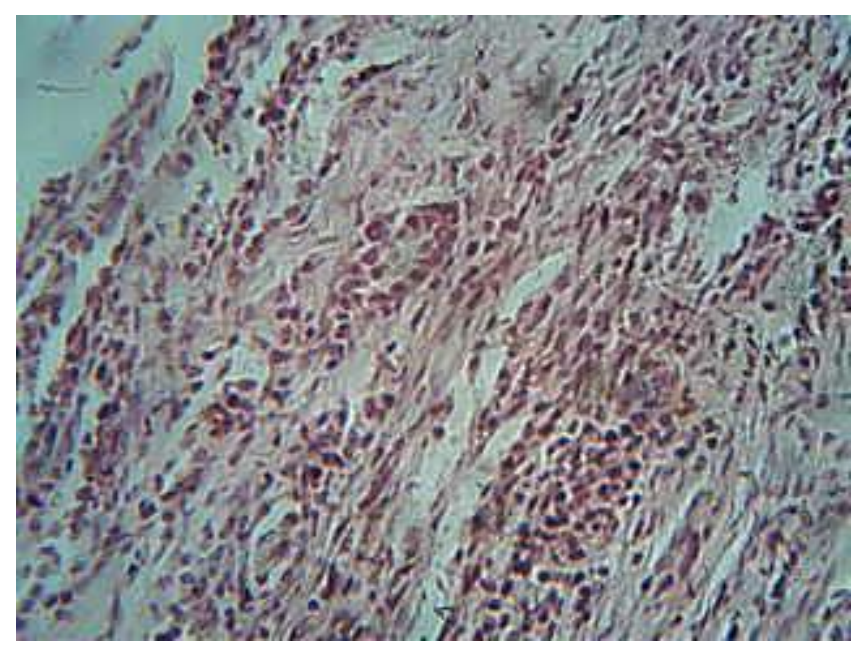

Fig.(2):Lung: There is severing infiltration of inflammatory cells (Macrophages \& Lymphocytes) in the pulmonary tissue with fibrosis. 100X H\&E. 


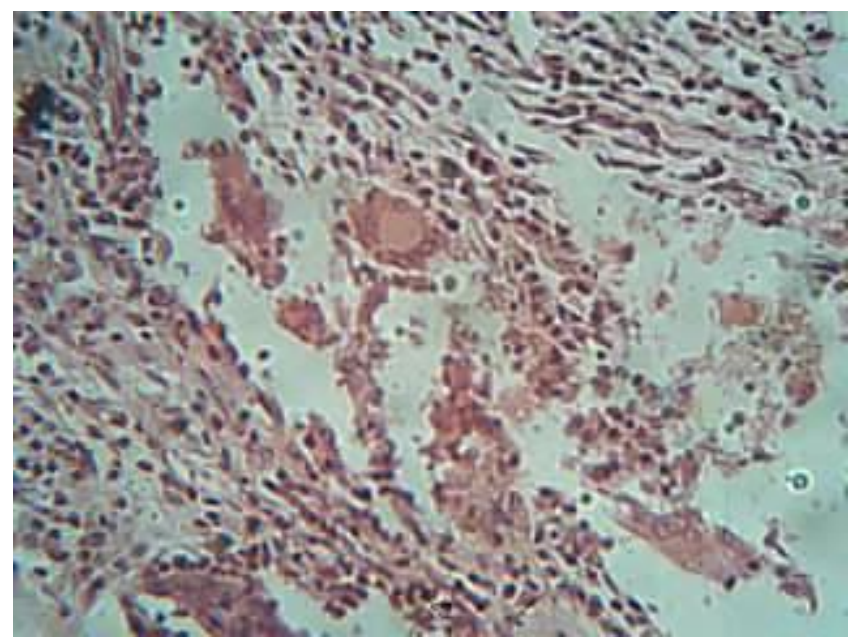

Fig.(3): Lung: There is multinucleated langhans giant cell (horse shoe like nucleus) in the pulmonary tissue. 50X H\&E.

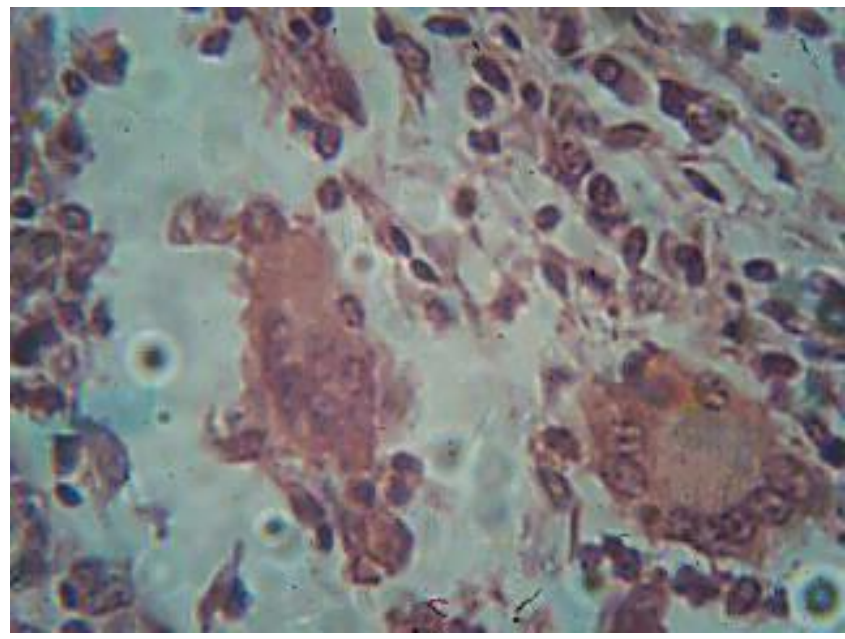

Fig.(4):Lung: There is multinucleated langhans giant cell (horse shoe like nucleus) in the pulmonary tissue. 100X H\&E.

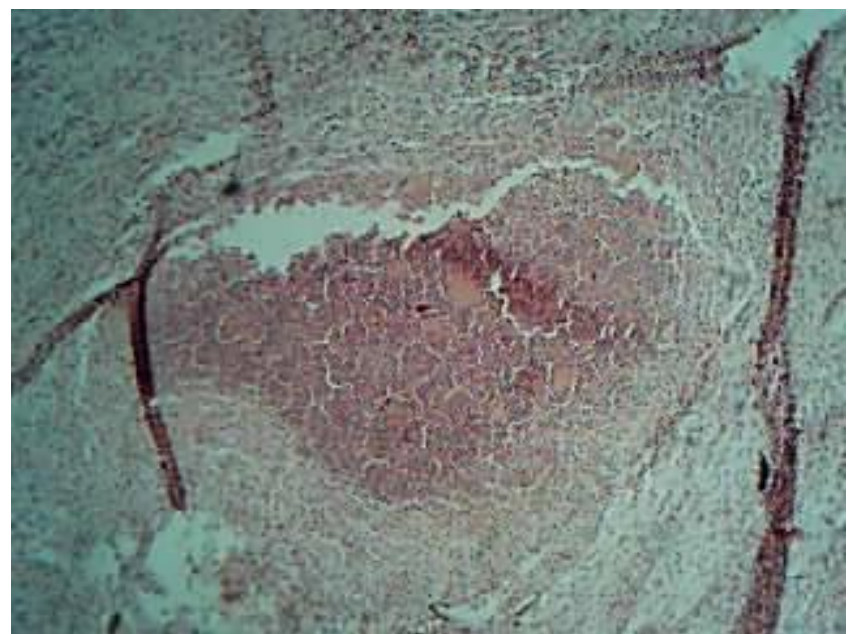

Fig.(5): Lung : There is granulomatous lesion (granuloma), note the caseous necrosis in center of lesion and infiltration of inflammatory cells (Macrophages \& Lymphocytes) and fibrous capsule around this lesion. 50X H\&E. 


\section{Discussion}

From our results, we showed that caseous necrosis considered as lesion associated with many diseases such as chronic diseases (tuberculosis, John's disease, fungal and parasitic diseases).Grossly we note the granuloma (granulomatous lesion) in lungs tissue of infected sheep with chronic diseases which appears yellowish green in color with caseous necrosis in center of lesion this agreed with (7), they described the gross lesion of caseous necrosis in bovine tuberculosis and described the tubercles in infected cattle.Also we showed from our results that the fibrosis (fibrous tissue proliferation) around the granulomatous lesion which indicate the chronic reaction for causative agent (bacteria such as mycobacterium, fungi, parasite \& other causative agent) (8), he show that Corynebacterium pseudotuberculosis infection in camels may cause granulomaous lesion surrounded by fibrous tissue.From our histological examination we note under microscope the chronic inflammatory response (Macrophage,

\section{Reference}

1.Porth C. M. \& Gaspard K.J. 2002. $6^{\text {th }}$ ed. Philadelphia. Baltimore, New York, London. Paper 33-34.

2.Dehen R. 2006. Pathology 1 fall 2006. pathology lectures. Page 4-6.

3.Alpert \& Thygesen, E,T. 2000. MYOCARDIAL INFARCTION REDEFINED. JACC Vol. 36, No. 3 :959-6

4.Robbins S.L., Kumar V., \& Cotran R.S. 2003. Robbins Basic pathology. International edition. PP. 21-27.

5.Marco V., Giorgio Z. and Elisabetta F.1997. APOPTOSIS vs. NECROSIS. published in the Purdue Cytometry CD-ROM Series, volume 4. 27: 1-20.

6.Luna L.G. (1968). Manual of histopathological staining methods of the armed forces, Institute of Pathology. $3^{\text {rd }}$ ed., McGraw Hill Book Company, N.Y., Toronto. London, Sydney; 12-31.
Lymphocyte \& plasma cells) which infiltrate into site of infection during few days until several months and cause line of demarcation around the caseous necrosis which present in the center of lesion. This agreed with (9), they described these inflammatory process in case of cutaneous leishmaniasis. This inflammatory response occur after infiltration of neutrophils which killed by causative agent. After neutrophils infiltration, lymphocytes and macrophages infiltrate into site of infection and these macrophages tend to kill causative agent but it can't to do this, So that Macrophages united together about (2-12 cells) to form multinucleated giant cell (which has horse shoe like nucleus) to kill the causative agent, this reported by (10), he described the granulomaous lesion in meningies of infected cattle, he reported the extensive necrotic areas (caseous necrosis) in meningies were surrounded by multinucleated giant cell, epitheloid macrophages, plasma cells, lymphocytes \& fibrous proliferation.

7.Shitaye J.E., Getahum B., Alemayehu T., Skoric M., Tremal F., Fictum P., Vrbas V. \& Pavlik I. (2005). A prevalence study of bovine tuberculosis by using abattoir meat inspection and tuberculin skin testing data, histopathological and IS611 PCR examination of tissues with tuberculosis lesions in cattle in Ethiopea. Veterinari Medicina, 51(11): 512-522.

8.Hawari A.D. 2008. Corynebacterium pseudotuberculosis infection (caseous lymphadenitis) in camels (Camelus dromendarium) in Jordan. American Journal of Animal and Veterinary science. 3(2): 68-72.

9.Peltier E., Wolkenstein P., Deniau M., Zafrani E.S., and Wechsler J. (1996).Caseous necrosis in cutaneous leishmaniasis. J Clin Pathol. June; 49(6): 517-519. 
10. Oruc E. (2005).

Meningoencephalitis Tuberculosa in a Holstein Cow. American college of veterinary pathologists.

Vet. Pathol, 42: 856-858.

\section{دراسة مرضية نسجية للنخر ألتجبني في رئات الأغنام في محافظة الايوانية

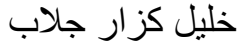 \\ كلية الطب البيطري/جامعة القادسية}

\section{الخلاصة}

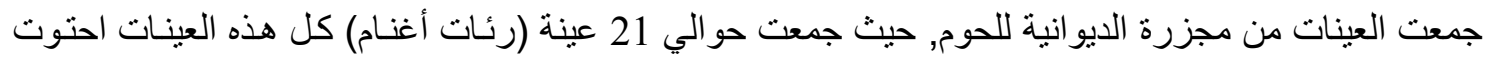

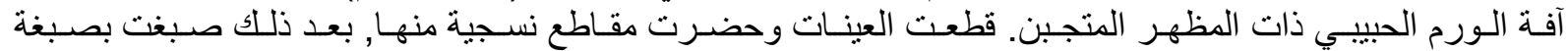

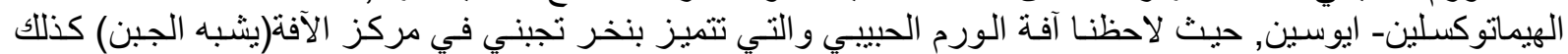

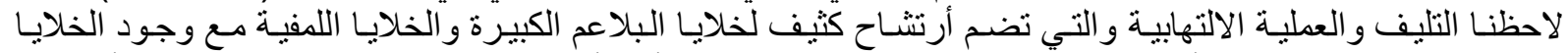

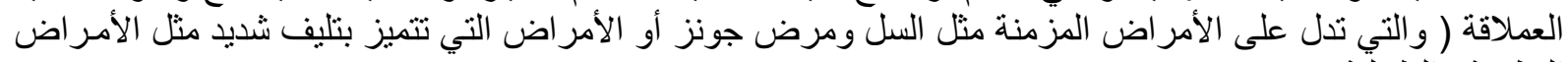

